\section{ROOTS OF RECOVERY}

Replanting coastal forests destroyed by last December's tsunami sounds like a good idea - especially if they protect against future storms. But such plans need nurturing if they are to succeed, Erika Check discovers.

$\mathrm{O}$ $\mathrm{n}$ a cloudy, humid day last month, 250 people gathered near the beach in the small Indonesian village of Kajhu. Local and international officials gave speeches, and some of the villagers performed a traditional dance ceremony. Then, everyone carried shovels and buckets along a gravel road past a flattened area of the beach littered with broken tree stumps. The buckets held tiny mangrove and Casuarina pine seedlings, which the villagers tucked into shallow trenches they dug at the water's edge.

Kajhu village is in the province of Aceh on Sumatra - the area most brutally devastated by last year's tsunami. Of the approximately 300,000 killed on 26 December 2004, more than 130,000 were from Aceh. The Kajhu ceremony was a small act of hope in the wake of tragedy. The replanting marked the launch of the Green Coast Programme, a plan drawn up by non-profit groups, international donors and the Indonesian government. The project is one of many across southeast Asia that aims to replace mangrove forests destroyed by the tsunami and by human industry.

Mangroves have been disappearing from southeast Asian coastlines for decades, replaced by vast shrimp farms and tourist resorts. In the five countries hit hardest by the tsunami, development eliminated 1.5 million hectares of mangroves between 1980 and 2000 $-26 \%$ of the region's mangrove cover ${ }^{1}$. But the devastation wrought by the tsunami has inspired governments to try to restore these ecosystems, which environmental scientists and economists have long said are natural defences against storm damage.

Mangrove restoration is notoriously difficult, however, and these replanting projects face huge challenges. Past restoration projects have planted the wrong species in the wrong places, scientists say. And the projects have tended to ignore, alienate or exploit the people living closest to the mangrove forests. "Local communities must have more of a say in the control, use and protection of mangroves,"

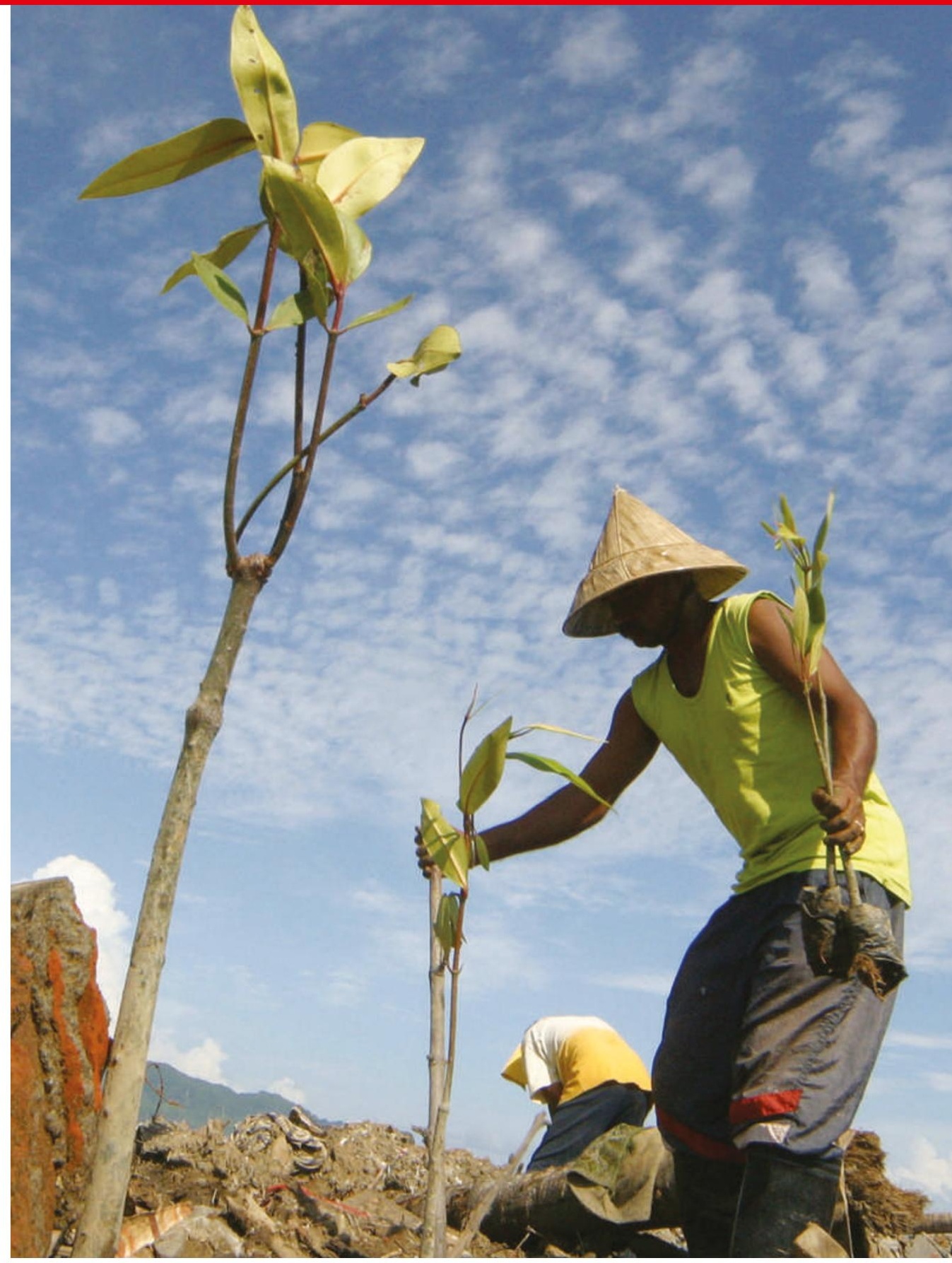

Green shield: workers near Banda Aceh plant mangroves in the hope of protecting their coastline.

says Ed Barbier, an environmental economist at the University of Wyoming in Laramie. Otherwise, future restoration projects will suffer the same fate as past ones - and fail to have any lasting results.

\section{Boom and bust}

The problem, says Alfredo Quarto, director of the Mangrove Action Project, Port Angeles, Washington, is that "mangrove areas are remote, usually public lands, available to lease by corrupt officials". Poor fishers and farmers rarely have any land rights and cannot prevent mangroves being cleared for shrimp ponds. "The people who enforce the laws don't live in these areas and can be convinced by someone with money to turn their backs on the destruction," Quarto says. When the farms collapse, due to disease or contamination, a wealthy owner can move on to another stretch of virgin coast, leaving a useless waste site behind ${ }^{2}$.

Shrimp farms create temporary jobs, but the boom-and-bust cycle hurts villages more than it helps. Healthy mangroves are nurseries for fish, crabs and other creatures that mature in the ocean. So eliminating the mangroves cuts off a source of food and income.

Mangrove deforestation compounded the effects of the tsunami. After the wave passed, villagers reported that areas with more mangrove cover suffered less damage. These anecdotal reports have been bolstered by analysis of satellite images taken before and after the tsunami. This October, international researchers coordinated by the Nordic Agency for Development and Ecology in Copenhagen, 
Denmark, reported that areas with mangrove or tree cover were significantly less likely to have experienced major tsunami damage ${ }^{3}$.

The authors caution that vegetation does not prevent the worst devastation, but they see a protective role for plants in reducing damage from regular storms, such as the typhoons that batter the Philippines every year. These findings supported the locals' perceptions that mangroves are natural barriers, says Vaithilingam Selvam of the M. S. Swaminathan Research Foundation in Chennai, India. "It used to take us years to convince people that mangroves are worth saving," Selvam says. "Now it is much easier, because people see them as a bioshield."

Many southeast Asian governments have now pledged their support for mangrove restoration. Malaysia has promised \$25 million to replace 4,000 hectares of mangroves lost to the storm and to development. Indonesia has pledged $\$ 22$ million for mangroves, and has already planted 300,000 seedlings near the city of Banda Aceh. The Thai government has expressed its support for mangrove restoration and coastal rebuilding. In India, the government of the southern state of Kerala has pledged $\$ 8$ million to supplement an existing programme to restore mangroves destroyed by cyclones. International donor groups also offered money and seedlings, and several meetings were set up to coordinate the restoration projects.

\section{Shifting ground}

How likely are these projects to succeed? Many of the seedlings planted on the Aceh coast earlier this year have already died, because they were planted too soon and in the wrong places, say scientists working in the region. "Sometimes the site selection was not so good, and there was still debris from the tsunami washing up that destroyed the seedlings," says Faizal Parish, an ecologist and director of the Global Environment Centre in Selangor, Malaysia. And the paid contractors had no reason to continue caring for the young, fragile shoots.

Getting it right is slower and more difficult, say the groups with long-term experience of mangrove restoration in Asia. The Wetlands International Indonesia Programme (WIIP), based in Bogor, Java, has been running projects since 1998. The group coordinates replanting projects by negotiating agreements with villages. The villagers commit to plant a certain number of seedlings they collect from the wild. In return, the programme provides support staff and a loan that the villagers can use to start businesses, such as chicken and goat farms.

If $70 \%$ of the seedlings are still alive after five years, the village keeps the money; otherwise it must repay part of the loan. Nyoman Suryadiputra, a wetlands ecologist and technical director of WIIP, says this encourages villagers both to plant and care for the forests, making them more likely to survive. So far, villagers have replanted 350 hectares of land

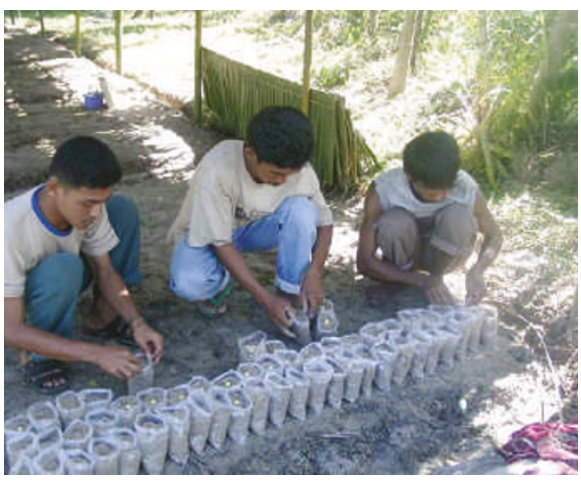

Mucking in: involving local people is one of the keys to a successful restoration project.

along 3.5 kilometres of Indonesian coast through these arrangements.

But rebuilding after the tsunami has been more challenging, Suryadiputra says, and covers a wider area. Some of the group's current activities focus on the Aceh coast, including the project in Kajhu. But the group has also begun work on Simeulue Island, $300 \mathrm{~km}$ southwest of Banda Aceh, which was hammered by the tsunami and its aftershocks.

Before the disaster, Wetlands International estimated that Simeulue Island had at least 1,000 hectares of mangrove swamps. But the tsunami - plus another earthquake that followed this March - lifted parts of the island by 1-2 metres, cutting off mangroves and coral reefs from the tidal waters that sustain them. And the islanders have been so devastated by these disasters that - understandably - planting trees is not their first priority. "Many of the people are still traumatized," Suryadiputra says.

So the group first had to convince Simeulue

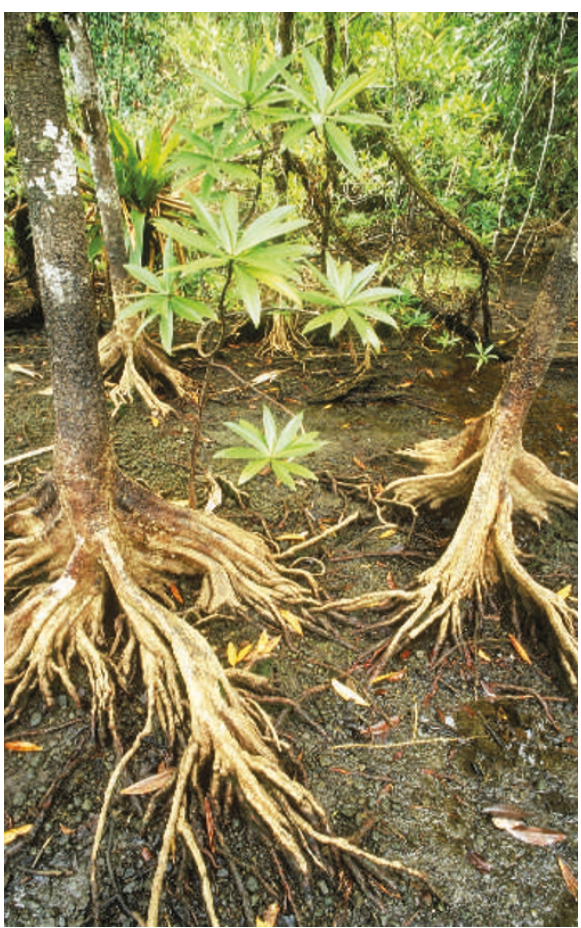

Under threat: southeast Asia has lost a quarter of its mangrove forest in the past 20 years. residents that planting trees would restore ${ }^{\infty}$ some of their lost livelihoods. This summer, staff member Eko Budi Priyanto persuaded villagers in Langi, on Simeulue Island, to plant a nursery of 5,000 Calophyllum tree seedlings grown from seeds they collected on the beach. Building the nursery brought the village together, as entire families pitched in to help. The seedlings are now about a metre tall and have just been planted, Suryadiputra says. "It's been a really big challenge, and I don't want to say our approach will be successful," he says. "We want to do this properly from the beginning, and that's not easy."

\section{Gathering storm}

The time and effort involved in communitybased programmes makes them harder to execute, but those with experience say approaches that involve local people are the only ones that make sense. In three states in India, where Selvam works, 33 villages have worked with forestry officials to restore 1,500 hectares of mangroves since 1993. So far, three-quarters of the seedlings have survived, Selvam says, double that of other techniques. The communities saw the benefits of their work when the trees buffered the impact of the tsunami, says Selvam, who is trying to enlist new villages in restoration projects.

The question is whether commitments to restoration will last longer than one year after the tsunami. Already, there are signs that governments and developers are returning to their old ways. In Indonesia, despite official support for buffer zones, shrimp farms destroyed in the tsunami are being rebuilt without setting aside space for trees. In some cases, says Parish, the Indonesian government has given newly damaged coastal land to developers, to create new shrimp farms. "These are strong pressures, as they were before," says Parish.

In many cases, local people are unhappy about these new developments, but they lack influence with government officials. This is the situation facing poor communities everywhere, not just in areas hit by the tsunami, says Jurgenne Primavera, a marine biologist at the Southeast Asian Fisheries Development Center in Iloilo, the Philippines. "The people who are at risk are poor, so they can't lobby the government to put protective greenbelts in the places where they live," says Primavera. The result in Indonesia, notes Parish, is that "the initial sensible plan to have some sort of greenbelt along the coast has not advanced as much as it could have."

The next storm in Kajhu is unlikely to be a tsunami, but without healthy mangroves it could still be devastating.

Erika Check is Nature's Washington

biomedical correspondent.

Food and Agriculture Organization State of the World's Forests (FAO, Rome, 2003)

2. Naylor, R. L. et al. Science 282, 883 (1998).

3. Danielsen, F. et al. Science 310, 643 (2005) 